\title{
Whiteness, power relations, resistance and the 'practical' recognition of Indigenous rights in Newcastle
}

\author{
Deirdre Howard-Wagner*
}

While fleeting references are made to Australian Federal Government policy shifts in light of different rationalities and modes of state governance, the paper is essentially a study of whiteness, power relations and resistance in Newcastle, Australia. It is framed within a discussion of the importance of history to local Kooris and Gooris in the struggle for the recognition of Indigenous rights. Specifically, the paper examines how local Koori and Goori discourses and practices expose and disrupt whiteness, as relations of power, in negotiations for the recognition of Awabakal sites and acknowledgement of local Awabakal history. That is, 'faced with a relationship of power, a whole field of responses, reactions, results, and possible inventions open up' (Foucault 1994: 340). The paper draws on field notes, documentary analysis, participant observation data and interview data collected while conducting a two year sociological ethnography of the recognition of Indigenous rights in Newcastle. [Article copies available for a fee from The Transformative Studies Institute. E-mail address:_journal@transformativestudies.org_Website: http://www.transformativestudies.org (C2009 by The Transformative Studies Institute. All rights reserved.]

KEYWORDS: Whiteness, Power Relations, Resistance, Indigenous Rights.

\footnotetext{
* Dr. Deirdre Howard-Wagner is the Director of the Bachelor of Socio-Legal Studies at the University of Sydney in Australia. Her area of research expertise is Indigenous people, law and society. Her work has made a significant socio-legal and sociological contribution to the study of Australian Federal Indigenous law and policy governing Indigenous affairs in the contemporary period, especially in the context of international human rights developments. She has contextualised this shift through sociological ethnographic research. Most recently, she has been writing a number of papers on the 'national emergency response' declared in the Northern Territory in 2007. Address correspondence to: Dr. Deirdre Howard-Wagner, University of Sydney, Department of Sociology and Social Policy, Room 157 RC Mills Building A26, Sydney, NSW Australia; tel: +61 29351 6679; e-mail: deirdre.howard-wagner@usyd.edu.au.
} 